\title{
High efficacy of CpG-ODN, Cetuximab and Cisplatin combination for very advanced ovarian xenograft tumors
}

Michele Sommariva ${ }^{1,3}$, Michelandrea de Cesare ${ }^{2}$, Alessandra Meini ${ }^{1,3}$, Alessandra Cataldo ${ }^{1,3}$, Nadia Zaffaroni $^{2}$, Elda Tagliabue ${ }^{3}$ and Andrea Balsari ${ }^{1,3^{*}}$

\begin{abstract}
Background: To mimic clinical treatment situations in advanced human ovarian disease, we tested the efficacy of CpG-oligodeoxynucleotides (CpG-ODN), synthetic DNA sequences recognized by Toll-like receptor 9 and able to induce innate/adaptive immune responses, in combination with other possible therapeutic reagents in ovarian carcinoma ascites-bearing athymic mice.
\end{abstract}

Methods: Mice injected i.p. with IGROV-1 ovarian cancer cells were treated at different stages of ascites progression for 4 weeks with CpG-ODN, alone or in combination with Bevacizumab, Polyinosinic:Polycytidylic acid (Poly(I): Poly(C)), Gefitinib, Cetuximab and Cisplatin. Median survival time (MST) was calculated for each group. IGROV-1 cells treated or not with Cetuximab were assayed for antibody-dependent cellular cytotoxicity by ${ }^{51} \mathrm{Cr}$-release assay, and for macrophage antibody-dependent cell-mediated phagocytosis by flow cytometry.

Results: In mice treated when ascitic fluid began to accumulate, CpG-ODN combined with Bevacizumab, Poly(I): Poly(C) or Gefitinib did not significantly increase MST as compared with that using CpG-ODN alone, whereas MST in mice treated with CpG-ODN plus Cetuximab was significantly increased ( $>103$ days for combination vs 62 days for $\mathrm{CpG}$ alone; $\mathrm{P}=0.0008$ ), with $4 / 8$ mice alive at the end of the experiment. In experiments in mice showing increased abdominal volume and body weight (27.9 $\pm 0.8 \mathrm{~g}$ after vs $23 \pm 1.1 \mathrm{~g}$ before tumor cell injection), treatment with Cisplatin in addition to CpG-ODN/Cetuximab led to significantly increased MST (105.5 days; $P=0.001$ ), with all mice still alive at 85 days, over that using CpG-ODN/Cetuximab (66 days), Cetuximab/Cisplatin (18.5 days), Cisplatin (23 days) or saline (16 days). At a very advanced stage of disease (body weight: $31.4 \pm 0.9 \mathrm{~g}$ ), when more than half of control mice had to be sacrificed 6 days after starting treatments, the triple-combination therapy still increased MST (45 days; $P=0.0089$ ) vs controls.

Conclusions: CpG-ODN combination therapies that enhance the immune response in the tumor microenvironment and concomitantly target tumor cells are highly efficacious even in experimental advanced malignancies. Although differences in the distribution of TLR9 in mice and humans and the enrichment of this receptor on innate immune cells of athymic mice must be considered, our results indicate a promising strategy to treat ovarian cancer patients with bulky ascites.

Keywords: CpG-ODN, TLR9, Ovarian cancer, Ascites, Monoclonal Antibody, Cisplatin

\footnotetext{
* Correspondence: andrea.balsari@unimi.it

${ }^{1}$ Dipartimento di Scienze Biomediche per la Salute, Università degli Studi di

Milano, via Mangiagalli 31, 20133, Milan, Italy

${ }^{3}$ Molecular Targeting Unit, Fondazione IRCCS - Istituto Nazionale Tumori, via

Amadeo 42, 20133, Milan, Italy

Full list of author information is available at the end of the article
}

\section{Biomed Central}

(c) 2013 Sommariva et al.; licensee BioMed Central Ltd. This is an Open Access article distributed under the terms of the Creative Commons Attribution License (http://creativecommons.org/licenses/by/2.0), which permits unrestricted use, distribution, and reproduction in any medium, provided the original work is properly cited. 


\section{Introduction}

Advanced tumor disease in humans is generally much less responsive than limited disease to most anti-cancer therapies. Testing of new cancer therapies in preclinical models for advanced human ovarian cancer remains rare. Treatment usually involves minimal disease and therapy-naïve tumors, possibly accounting for the failure to reproduce encouraging preclinical results in subsequent Phase I/Phase II clinical trials [1].

CpG-ODNs are synthetic DNA sequences that mimic bacterial DNA and are recognized by the Toll-like receptor 9 (TLR9) member of the TLR family as a "danger signal" $[2,3]$ consisting of pathogen-associated molecular patterns or stress-induced self molecules [4]. Interaction of CpG-ODN with TLR9 can result in the generation of both innate and adoptive immune responses, either of which have the potential to significantly impact tumor growth. CpG-ODN have demonstrated antitumor activity in different animal models [5,6] and in patients with malignant melanoma, renal carcinoma and recurrent or refractory lymphoma [7-10]. However, although both preclinical and early clinical trials suggest the value of CpG-ODN as a component of various approaches to cancer therapy, clinical development of this recently discovered novel class of immunostimulatory agents is in the incipient stage and much remains unknown about their optimal use [11]. Our recent studies revealed that local, but not systemic, and daily, but not weekly, stimulation of immune effector cells by CpG-ODN targeted immunotherapy inhibited ascites production and significantly prolonged survival in human ovarian carcinoma ascites-bearing athymic mice [12]. However, CpG-ODN monotherapy might be sufficient to induce tumor regression only in small tumors; for larger tumors, CpGODN needs to be combined with other effective antitumor strategies [8]. Indeed, further evaluation in our advanced-stage human ovarian tumor-bearing mouse model showed that CpG-ODN combined with the DNA-damaging chemotherapeutic drug cisplatin, which is currently used in ovarian cancer patients [13], significantly increased the lifespan of mice compared with the individual treatments [14]. Interestingly, we found that CpG-ODN treatment at the tumor site down-modulated DNA repair genes in tumor cells [14]. The findings that peri-tumoral delivery of CpG-ODN is critical in DNA repair gene down-modulation in tumors but that CpGODN does not interact directly with the tumor cells to induce this down-modulation points to the importance of the activation of TLR9-positive cells. Because CpGODN-induced activation of TLR9-positive cells in the tumor microenvironment might also induce increased therapeutic activity of other drugs with different mechanisms of action, we used IGROV-1 ovarian carcinoma ascites-bearing athymic mice to evaluate the efficacy of
CpG-ODN combined with: the monoclonal antibody (MAb) Bevacizumab targeting the vascular endothelial growth factor (VEGF) [15,16], which is reportedly overexpressed in ovarian cancer [17-19] and which regulates angiogenesis as an important component of ovarian cancer growth [16,20]; Poly(I):Poly(C), a TLR3 agonist reported to synergize with TLR9 ligand to mediate enhanced activation of innate immunity [21]; MAb Cetuximab, which targets the ligand-binding domain of the epidermal growth factor receptor (EGFR) frequently expressed in ovarian cancer cells [20]; and Gefitinib, a tyrosine kinase inhibitor of EGFR. Our observation that CpG-ODN plus Cetuximab strongly increases survival over that seen with either reagent alone led to analysis of the efficacy of a therapeutic protocol involving CpG-ODN, Cetuximab and Cisplatin in mice with very advanced ovarian tumors.

\section{Materials and methods}

Mice

Eight- to 12-week-old female Swiss nude (athymic) mice (Charles River, Calco, Italy) were maintained in laminarflow rooms at constant temperature and humidity, with food and water given ad libitum. Experiments were approved by the Ethics Committee for Animal Experimentation of the Fondazione IRCCS Istituto Nazionale Tumori of Milan according to institutional guidelines.

\section{ODNs and drugs}

Purified, phosphorothioated ODN1826 (5'-TCCATGA CGTTCCTGACGTT-3') containing CpG motifs was synthesized by TriLink Biotechnologies (San Diego, CA, USA). Phosphorothioate modification was used to reduce susceptibility of the ODN to DNase digestion, thereby significantly prolonging its in vivo half-life. The following drugs were used: Bevacizumab (Roche, Basel, Switzerland); Poly(I)Poly(C) (Amersham Biosciences, Piscataway, NJ, USA); Cetuximab (Erbitux ${ }^{\circledR}$, Merck Serono, Darmstadt, Germany); Gefitinib (LC Laboratories, Woburn, MA, USA); and Cisplatin (Teva Italia, Milan, Italy). Lyophilized ODN1826 and Poly(I):Poly(C) were dissolved in sterile water at a concentration of $10 \mathrm{mg} / \mathrm{ml}$ and $2 \mathrm{mg} / \mathrm{ml}$, respectively, and stored at $-20^{\circ} \mathrm{C}$ until use. Gefitinib was dissolved in DMSO (10\% v/v final concentration) and diluted in carboxymethylcellulose $(0.25 \% \mathrm{w} / \mathrm{v})$ to a final concentration of $10 \mathrm{mg} / \mathrm{ml}$. Bevacizumab, Cetuximab and Cisplatin (purchased in their commercial formulation) were diluted in $200 \mu \mathrm{l}$ of sterile saline at the indicated concentrations just before administration.

\section{Cell culture}

For in vitro experiments, human IGROV-1 ovarian tumor cells (gift from Dr. J. Benard, Institute Gustave Roussy, Villejuif, France) [22] were cultured in RPMI 
medium 1640 supplemented with 10\% FCS (Sigma, St. Louis, MO) and $2 \mathrm{mM}$ glutamine (Cambrex, East Rutherford, NJ, USA) (complete medium). Mouse leukemic monocyte/macrophage RAW 264.7 cells (American Type Culture Collection) were cultured in DMEM (Sigma) supplemented with 10\% FCS (Sigma) and $2 \mathrm{mM}$ glutamine (Cambrex). All cultures were maintained at $37^{\circ} \mathrm{C}$ in a $5 \%$ $\mathrm{CO}_{2}$ humidified environment.

\section{Therapy studies}

IGROV-1 human ovarian carcinoma cells were adapted to growth i.p. and maintained by serial i.p. passages of ascitic cells into healthy mice as described [22]. Mice were injected i.p. with $2.5 \times 10^{6}$ ascitic cells in $0.2 \mathrm{ml}$ of saline and treated 7 days later, when ascitic fluid began to accumulate, with CpG-ODN i.p. daily for 4 weeks $(20 \mu \mathrm{g} /$ mouse) in combination with: Bevacizumab (5 mg/kg i.p. at 3-4 day intervals); Poly(I):Poly(C) (20 $\mu \mathrm{g} /$ mouse i.p. at 2-3 day intervals); Gefitinib (100 mg/kg per os, 5 days/ week); or Cetuximab (1 $\mathrm{mg} / \mathrm{mouse}$ i.p. at $3-4$ day intervals). Single agents were also included and control mice received saline.

In other experiments, mice with evident and established ascites were selected on the basis of a similar body weight (mean 27.9 $\pm 0.84 \mathrm{~g}, 31.4 \pm 0.9 \mathrm{~g}$, first and second experiment, respectively) from large groups of mice injected i.p. 11-12 days before IGROV-1 cell injection and randomly divided into saline-treated (controls) and groups treated with CpG-ODN, Cetuximab (both with the schedules reported above) and Cisplatin ( $3 \mathrm{mg} / \mathrm{Kg}$ i.p., once weekly for 4 weeks) or their combinations. Experimental groups (5-12 mice/group) were inspected daily for ascites formation and weighed three times weekly. Mice were individually sacrificed by cervical dislocation prior to impending death. Day of sacrifice was considered day of death, and the median day of death (median survival time; MST) was calculated for each group. Anti-tumor activity was assessed as the ratio of MST in treated vs. control mice $\times 100(\mathrm{~T} / \mathrm{C} \%)$.

\section{Flow cytometry}

IGROV-1 cells were exposed to Cetuximab $(5 \mu \mathrm{g} / \mathrm{m})$ for $72 \mathrm{~h}$ or left untreated, collected and incubated for $30 \mathrm{~min}$ at $4^{\circ} \mathrm{C}$ with anti-MICA, -MICB, -ULBP1, -ULBP2, ULBP4, -CD112, -CD155, -ICAM-1, and HLA-E antibodies (R\&D Systems; Minneapolis, MN. USA), followed by incubation with anti-mouse Alexa Fluor 448conjugated reagent (Invitrogen). Samples were analyzed by gating on live cells using FACSCanto II system (Becton-Dickinson, San Jose, CA) and BD FACSDiva ${ }^{\text {TM }}$ software (Becton-Dickinson). EGFR expression levels on IGROV-1 cells were determined after incubation for $30 \mathrm{~min}$ at $4^{\circ} \mathrm{C}$ with Cetuximab $(10 \mu \mathrm{g} / \mathrm{ml})$, followed by incubation with anti-mouse Alexa Fluor 448-conjugated antibody (Invitrogen).

\section{Antibody-dependent cellular cytotoxicity (ADCC) assay}

IGROV-1 cells were treated or not (controls) with Cetuximab $(5 \mu \mathrm{g} / \mathrm{ml}$ for $72 \mathrm{~h})$ and labeled with $100 \mu \mathrm{Ci}{ }^{51} \mathrm{Cr}$ (PerkinElmer, Waltham, Massachusetts) for $1 \mathrm{~h}$ at $37^{\circ} \mathrm{C}$. After 3 washes with PBS-5\% FCS, cells were co-incubated for $4 \mathrm{~h}$ at $37^{\circ} \mathrm{C}$ with PBMC from 12 healthy donors (effector:target ratio 50:1) in $200 \mu \mathrm{l}$ RPMI 1640 complete medium in triplicate 96-well U-bottomed plates in the presence of saturating concentrations of Cetuximab $(10 \mu \mathrm{g} / \mathrm{ml})$. Radioactivity of the supernatant $(80 \mu \mathrm{l})$ was measured with a Trilux Beta Scintillation Counter (PerkinElmer). Percent specific lysis was calculated as: $100 \times$ (experimental cpm - spontaneous cpm)/ (maximum cpm - spontaneous cpm).

\section{Phagocytosis assay}

Macrophage antibody-dependent cell-mediated phagocytosis (ADCP) was assessed by flow cytometry [23]. Murine RAW264.7 effector cells were labeled with PKH26 (Red Fluorescent Cell Linker Mini Kit), while IGROV-1 target cells were labeled with PKH67 (Green

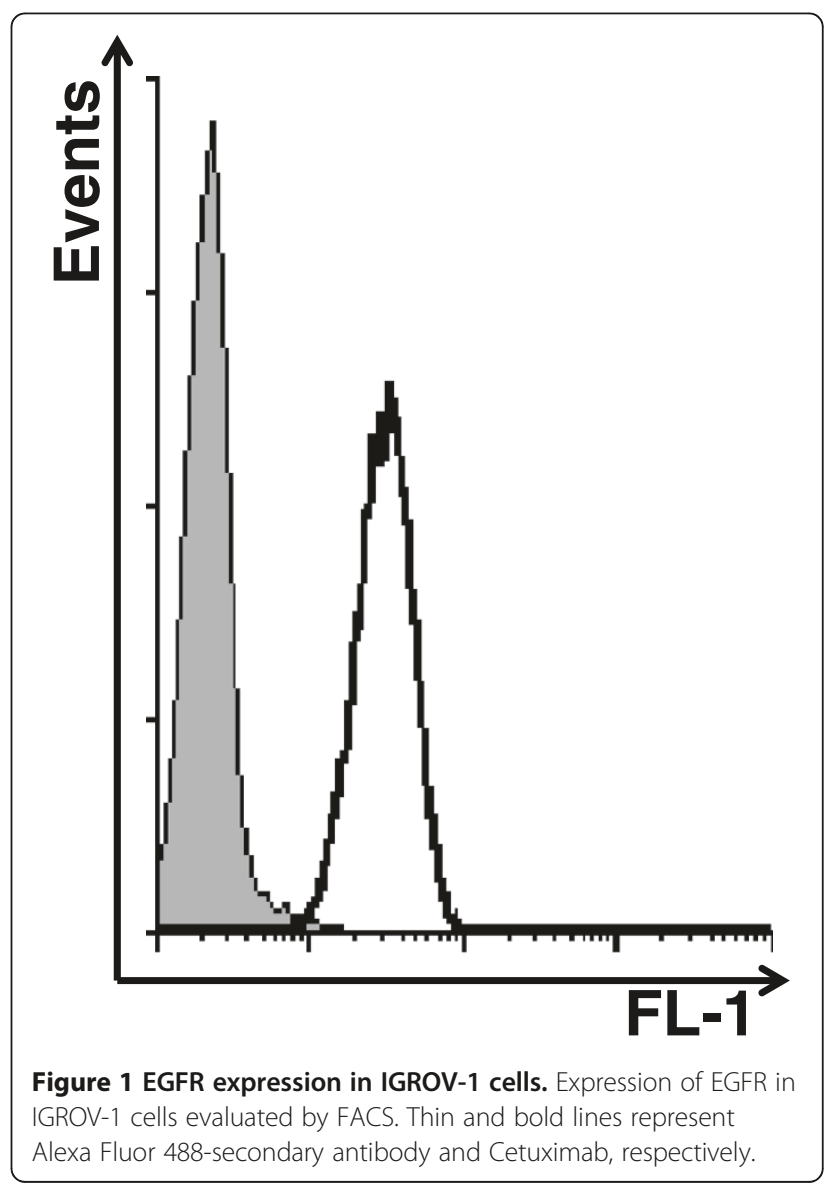


Fluorescent Cell Linker Mini Kit) according to the manufacturer's instructions (Sigma). IGROV-1 cells were then seeded in tissue culture flasks and exposed to Cetuximab $(5 \mu \mathrm{g} / \mathrm{ml}$ for $72 \mathrm{~h})$ or left untreated. At the end of treatment, target and effector cells were mixed at $\mathrm{E}: \mathrm{T}$ ratio of $3: 1$ in complete medium and incubated for $12 \mathrm{~h}$ at $37^{\circ} \mathrm{C}$ in overload conditions of monoclonal antibody $(10 \mu \mathrm{g} / \mathrm{ml})$. Cells were collected, washed, resuspended in cold $\mathrm{Ca}^{2+}$ - and $\mathrm{Mg}^{2+}$-free Dulbecco's PBS and analyzed by flow cytometry (FACSCanto II, BectonDickinson). Phagocytosis of IGROV-1 cells by RAW264.7 cells was evaluated in triplicate as percentage and intensity of macrophages positive for green fluorescence in at least three separate experiments.

\section{Statistical analysis}

Percent survivorship was estimated by the Kaplan-Meier product limit method and compared with the log-rank test.

\section{Results and discussion}

The efficacy of CpG-ODN in combination with Poly(I): Poly $(\mathrm{C})$, Bevacizumab, Cetuximab, or Gefitinib was evaluated in mice injected i.p. with IGROV-1 cells (which express EGFR, Figure 1) and treated on day 7, when ascitic fluid began to accumulate. Repeated i.p. CpGODN treatments plus Poly(I):Poly $(\mathrm{C})$ induced negligible effects on MST (65 days, T/C\% 325) compared with CpG-ODN treatment alone (61 days, T/C\% 305), with 2 of 9 mice from the combined treatment group showing long-term survival at the end of the experiment (120 days) (Figure 2). The previously observed synergy between the two immune modulators [21] was not seen, possibly due to the schedule of CpG-ODN administration; indeed, daily CpG-ODN administration might induce massive innate cell activation hardly expandable by other immune modulators.

Repeated i.p. CpG-ODN treatments plus anti-VEGF Bevacizumab (Figure 2) also did not enhance the effect of CpG-ODN treatment alone (MST 56 days for the combination vs 62 days for CpG-ODN alone). Of note, Bevacizumab as a single agent delayed the onset of ascites (data not shown), consistent with recent preclinical and clinical data and suggesting that targeting VEGF might suspend ascites production resulting from peritoneal metastasis [24].

The combination of the EGFR tyrosine kinase inhibitor Gefitinib and repeated i.p CpG-ODN induced only a modest increase $(\mathrm{p}=0.4099)$ in lifespan (MST 67 days, $\mathrm{T} / \mathrm{C} \%$ 372) compared with that in mice treated with

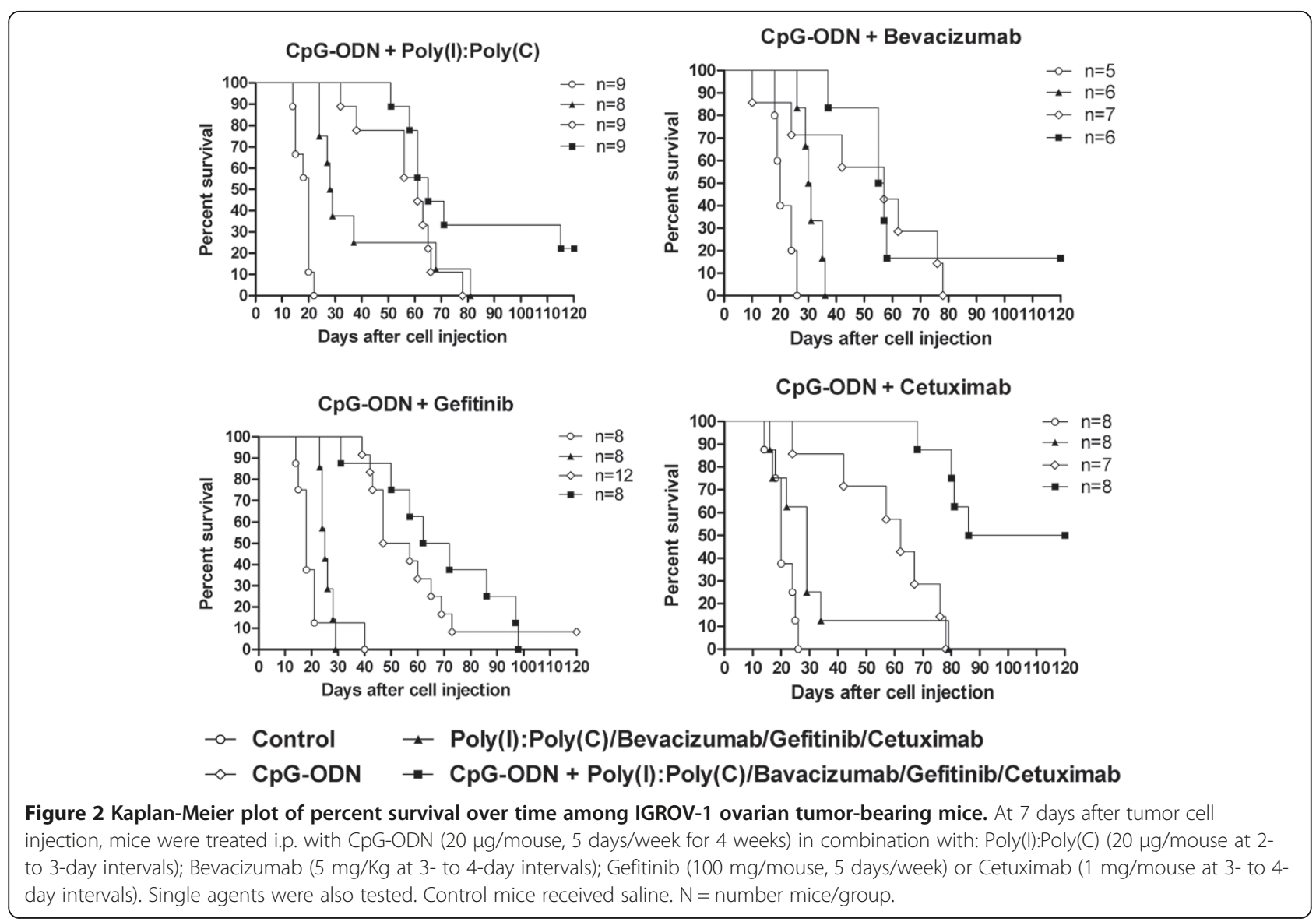


CpG-ODN alone (MST 52 days, T/C\% 289), whereas survival was significantly increased $(p=0.0008)$ in mice treated with CpG-ODN plus Cetuximab (MST > 103 days) versus those treated with CpG-ODN alone (MST 62 days) (Figure 2), with 4 of 8 mice still alive at the end of the experiment. The latter finding most likely reflects CpGODN-induced recruitment and activation of immune effector cells at the site of tumor growth [25-27]; nevertheless these impressive results in a model in which the antibody alone had slight effect might be also related to a Cetuximab-induced increase in susceptibility of tumor cells to CpG-ODN-activated effector cells involved in ADCC and/or in phagocytosis $[28,29]$.

Because HER signaling in tumors regulates expression of MICA and MICB, key ligands that promote NK cellmediated recognition and cytolysis [30], and because EGFR inhibitors enhance susceptibility to NK cellmediated lysis by modulating expression of the NKG2D ligand ULBP-1 [30-32], we tested whether Cetuximab treatment of IGROV-1 cells modulates expression of molecules involved in NK-mediated lysis (MICA, MICB, ULBP1, ULBP2, ULBP4, CD112, CD155, ICAM-1 and

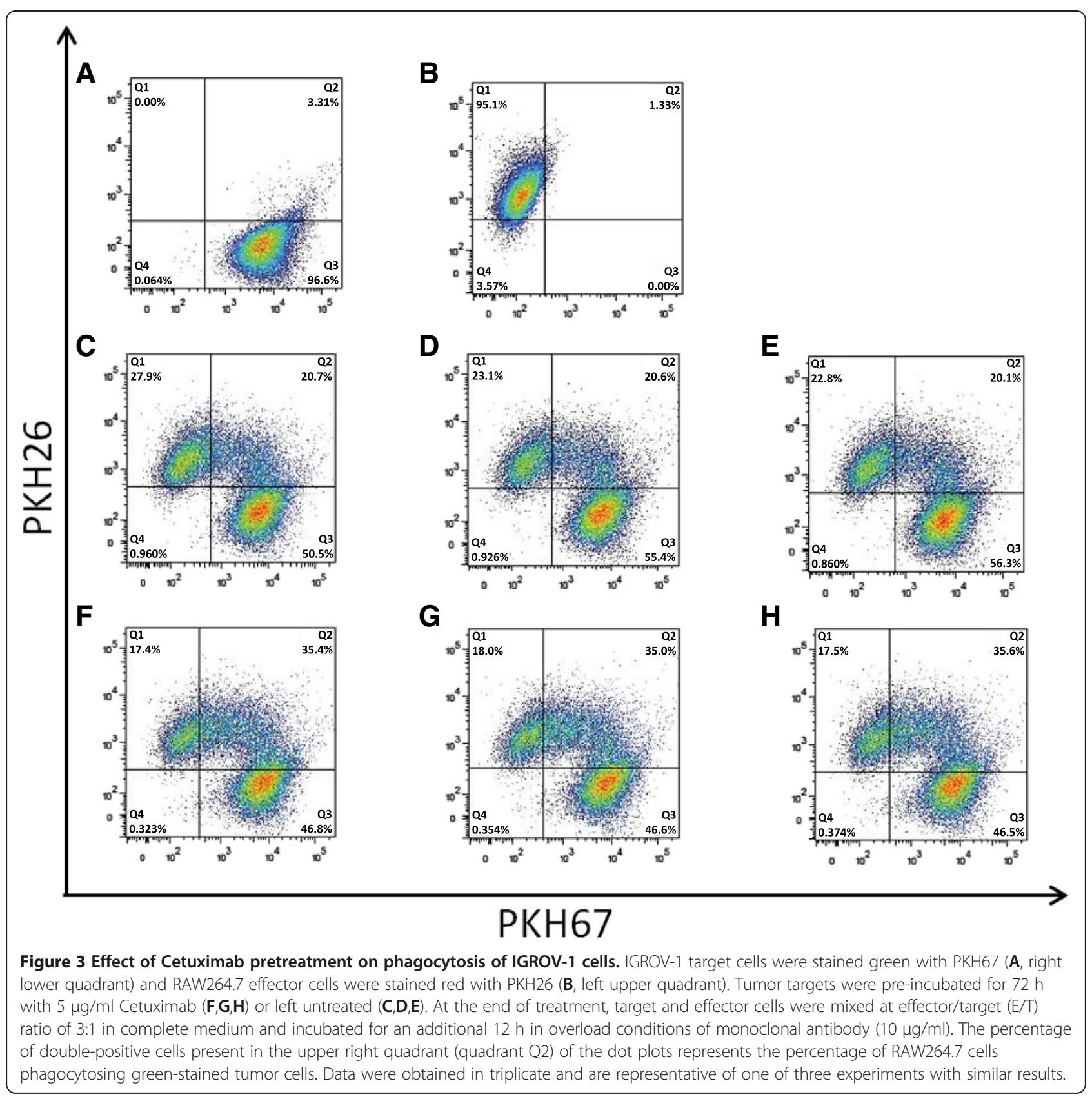


HLA-E). FACS analysis of tumor cells pretreated with Cetuximab $(5 \mu \mathrm{g} / \mathrm{ml})$ for $72 \mathrm{~h}$ revealed no significant effect on expression of any these molecules (data not shown). Moreover, ${ }^{51} \mathrm{Cr}$-release ADCC assay using Cetuximabpretreated or untreated IGROV-1 cell targets and PBMC from 12 healthy donors as effectors revealed no increase in death percentage in the pretreated tumor cells (data not shown). By contrast, in in vitro phagocytosis experiments carried out in overload Cetuximab antibody conditions, IGROV-1 cells pretreated with Cetuximab were more
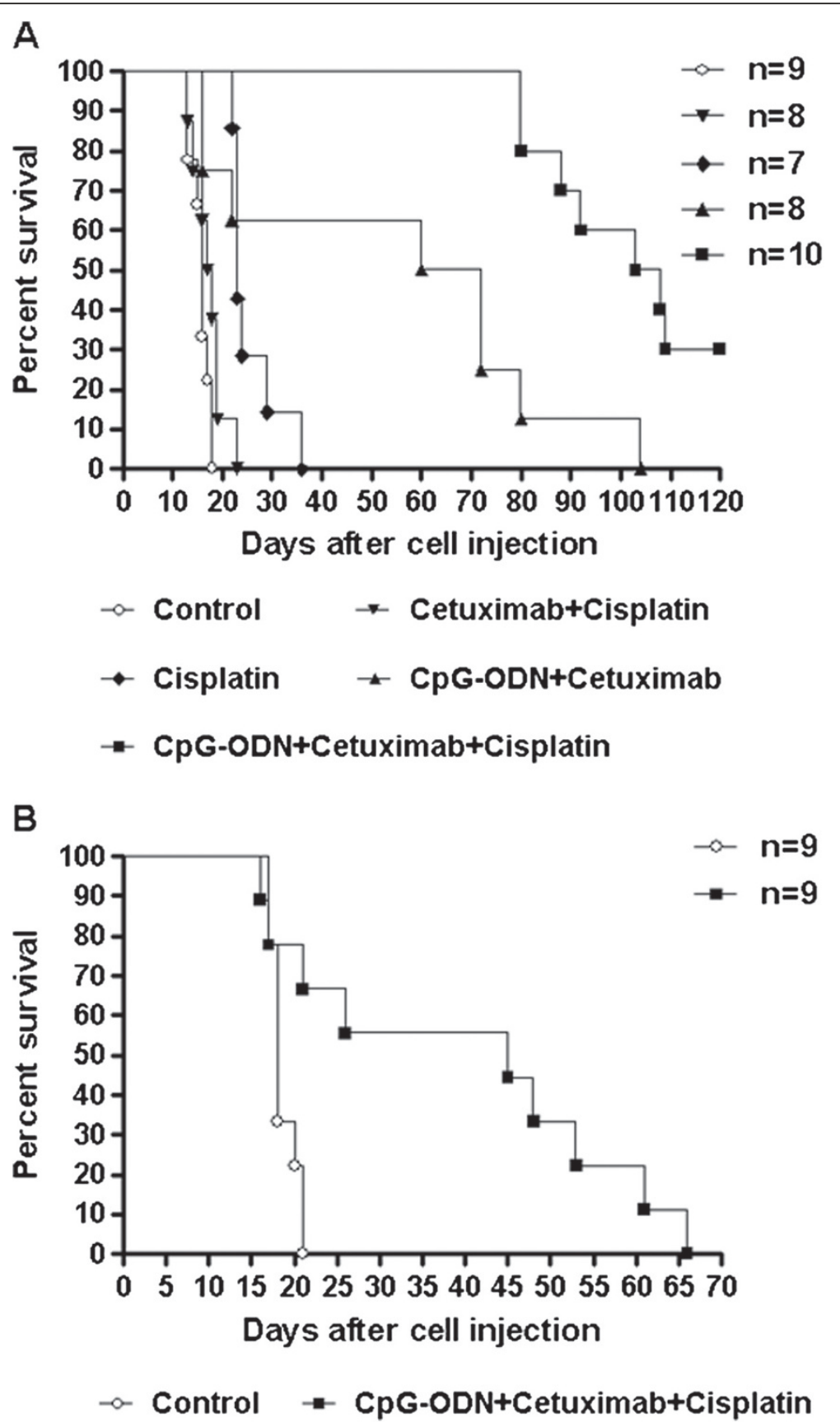

Figure 4 Kaplan-Meier plot of percent survival over time in advanced-stage IGROV-1 ovarian tumor-bearing mice. (A) Mice selected for the presence of evident and established ascites from a large group of mice injected i.p. 11 days before with IGROV-1 cells (mean body weight \pm SEM $27.89 \pm 0.84 \mathrm{~g}$ vs $23.00 \pm 1.08 \mathrm{~g}$ before tumor cell injection) were treated with saline, Cisplatin ( $3 \mathrm{mg} / \mathrm{kg}$, once per week), CpG-ODN (20 $\mu \mathrm{g} /$ mouse, 5 days/week for 4 weeks) plus Cetuximab (1 mg/mouse at 3- to 4-day intervals), CpG-ODN plus Cisplatin, Cetuximab plus Cisplatin, and CPG-ODN plus Cetuximab and Cisplatin. (B) Mice selected for more advanced-stage disease (mean body weight \pm SEM $31.4 \pm 0.9 \mathrm{~g}$ vs $24.89 \pm 0.68 \mathrm{~g}$ before tumor cell injection) were treated with saline or CpG-ODN plus Cetuximab and Cisplatin. $\mathrm{N}=$ number mice/group. 
robustly phagocytosed by RAW264-7 macrophages (Figure 3) as compared to control cells. These findings raise the possibility that Cetuximab also increases susceptibility to phagocytosis of tumor cells in vivo and suggest that the strong anti-tumor activity observed in the CpG-ODN/Cetuximab treatment might be due in part to increased susceptibility to phagocytosis of tumor cells induced by Cetuximab.

EGFR inhibitors reportedly also interact with Cisplatin [33-36], although their effect on sensitivity to this drug remains undefined. Based on our recent report of synergy between CpG-ODN and Cisplatin [14], we investigated the therapeutic effect of the combination of CpG-ODN, Cetuximab and Cisplatin in mice selected for evident and established ascites from a large group of mice injected i.p. 11 days before with IGROV-1 cells (mean body weight \pm SEM $27.9 \pm 0.84 \mathrm{~g}$ vs $23.00 \pm 1.08 \mathrm{~g}$ before tumor cell injection; increased body weight $=4.9 \mathrm{~g}$ ). Mice were randomly divided into different groups and treated with saline, Cisplatin, CpG-ODN plus Cetuximab, CpG-ODN plus Cisplatin, Cetuximab plus Cisplatin, and CpG-ODN plus Cetuximab and Cisplatin. Saline-, Cisplatin-, or Cetuximab/Cisplatin-treated mice were euthanized on days 13 to 36 after tumor cell injection (MST 16, 23 and 18.5 days, respectively), CpG-ODN/Cetuximab-treated mice were euthanized between days 16-104 (MST 66 days; $\mathrm{T} / \mathrm{C} \%=412.5$ ), while 7 mice treated with the triple combination were euthanized on days 80-109, with 3 still alive at the end of experiment. Thus, survival was significantly increased (MST 105.5; T/C\% 659.37; $\mathrm{P}=0.001$ ) compared with CpG-ODN/Cetuximab-treated mice (Figure 4A). Similar analysis in mice bearing even more advancedstage ascites (mean body weight \pm SEM $31.4 \pm 0.9$ g vs $24.89 \pm 0.68 \mathrm{~g}$ before tumor cell injection; increased body weight $=6.51 \mathrm{~g}$ ) showed that the CpG-ODN/Cetuximab/ Cisplatin combination still increased survival (MST 45; $\mathrm{T} / \mathrm{C} \% 250, \mathrm{P}=0.0089$ vs controls) (Figure $4 \mathrm{~B}$ ). Note that 6 days after the start of treatment, 6 of 9 salinetreated mice became moribund and were sacrificed.

\section{Conclusions}

Preclinical studies in which treatment is initiated only after ascites is evident are rare and generally show a small effect on survival. Our results indicate that combination therapies to concomitantly enhance the immune response in the tumor microenvironment and target tumor cells can be effective even in advanced malignancies. Although differences in the distribution of TLR9 receptors in mice and humans as well as the enrichment of innate immune cells in athymic mice must be considered, our findings point to a promising clinical strategy for treating ovarian cancer patients with bulky ascites. Thus, clinical trials of i.p. CpG-ODN treatment in association with Cetuximab and Cisplatin might now be contemplated in ovarian carcinoma patients with bulky disease.

\section{Abbreviations}

CpG-ODN: CpG-oligodeoxynucleotides; Poly(I):Poly(C): Polyinosinic: Polycytidylic acid; MST: Median Survival Time; TLR: Toll-like receptor; MAb: Monoclonal Antibody; EGFR: Epidermal Growth Factor Receptor; i.p.: intraperitoneal; T/C\%: Treated/Control*100; ADCC: Antibody-Dependent Cellular Cytotoxicity; ADCP: Antibody-Dependent Cell-mediated Phagocytosis.

\section{Competing interests}

The authors declare that they have no competing interest.

\section{Authors' contributions}

$A B, M S$ conceived the study. MS, MDC performed the in vivo experiments. $A M, A C, M S$ carried out the ADCC, phagocytosis assay, and the other in vitro experiments. $A B, M S, A M$ analyzed the data. $A B$, drafted the manuscript. MS, AM helped to draft the manuscript. ET, NZ revised critically manuscript for important intellectual content. All the authors read and approved the final manuscript.

\section{Acknowledgments}

This work was supported by AIRC (Associazione Italiana per la Ricerca sul Cancro). M.S. was supported by "Dote ricerca": FSE, Regione Lombardia.

\section{Author details}

${ }^{1}$ Dipartimento di Scienze Biomediche per la Salute, Università degli Studi di Milano, via Mangiagalli 31, 20133, Milan, Italy. ${ }^{2}$ Molecular Pharmacology Unit, Fondazione IRCCS - Istituto Nazionale Tumori, via Amadeo 42, 20133, Milan, Italy. ${ }^{3}$ Molecular Targeting Unit, Fondazione IRCCS - Istituto Nazionale

Tumori, via Amadeo 42, 20133, Milan, Italy.

Received: 28 November 2012 Accepted: 23 January 2013

Published: 29 January 2013

\section{References}

1. Man S, Munoz R, Kerbel RS: On the development of models in mice of advanced visceral metastatic disease for anti-cancer drug testing. Cancer Metastasis Rev 2007, 26(3-4):737-747.

2. Schnare M, Barton GM, Holt AC, Takeda K, Akira S, Medzhitov R: Toll-like receptors control activation of adaptive immune responses. Nat Immunol 2001, 2:947-950.

3. Takeda K, Akira S: Toll-like receptors in innate immunity. Int Immunol 2005, 17(1):1-14.

4. Matzinger P: Tolerance, danger, and the extended family. Annu Rev Immunol 1994, 12:991-1045.

5. Carpentier AF, Chen L, Maltonti F, Delattre JY: Oligodeoxynucleotides containing CpG motifs can induce rejection of a neuroblastoma in mice. Cancer Res 1999, 59:5429-5432.

6. De Cesare M, Calcaterra C, Pratesi G, Gatti L, Zunino F, Ménard S, Balsari A: Eradication of ovarian tumor xenografts by locoregional administration of targeted immunotherapy. Clin Cancer Res 2008, 14:5512-5518.

7. Link BK, Ballas ZK, Weisdorf D, Wooldridge JE, Bossler AD, Shannon M, Rasmussen WL, Krieg AM, Weiner GJ: Oligodeoxynucleotide CpG 7909 delivered as intravenous infusion demonstrates immunologic modulation in patients with previously treated non-Hodgkin lymphoma. J Immunother 2006, 29:558-568.

8. Krieg AM: Toll-like receptor 9 (TLR9) agonists in the treatment of cancer. Oncogene 2008, 27:161-167.

9. Hofmann MA, Kors C, Audring H, Walden P, Sterry W, Trefzer U: Phase 1 evaluation of intralesionally injected TLR9-agonist PF-3512676 in patients with basal cell carcinoma or metastatic melanoma. J Immunother 2008, 31:520-527.

10. Leonard JP, Link BK, Emmanouilides C, Gregory SA, Weisdorf D, Andrey J, Hainsworth J, Sparano JA, Tsai DE, Horning S, Krieg AM, Weiner GJ: Phase I trial of toll-like receptor 9 agonist PF-3512676 with and following rituximab in patients with recurrent indolent and aggressive non Hodgkin's lymphoma. Clin Cancer Res 2007, 13:6168-6174.

11. Krieg AM: CpG still rocks! Update on an accidental drug. Nucleic Acid Ther 2012, 22:77-89. 
12. De Cesare M, Sfondrini L, Campiglio M, Sommariva M, Bianchi F, Perego P, van Rooijen N, Supino R, Rumio C, Zunino F, Pratesi G, Tagliabue E, Balsari $A$ : Ascites regression and survival increase in mice bearing advancedstage human ovarian carcinomas and repeatedly treated intraperitoneally with CpG-ODN. J Immunother 2010, 33:8-15.

13. Markman M: Pharmaceutical management of ovarian cancer: current status. Drugs 2008, 68:771-789.

14. Sommariva M, De Cecco L, De Cesare M, Sfondrini L, Ménard S, Melani C, Delia D, Zaffaroni N, Pratesi G, Uva V, Tagliabue E, Balsari A: TLR9-agonists oppositely modulate DNA-repair genes in tumor vesus immune cells and ehance chemotherapy effects. Cancer Res 2011, 71:6382-6390.

15. Hu L, Hofmann J, Jaffe RB: Phosphatidylinositol 3-kinase mediates angiogenesis and vascular permeability associated with ovarian carcinoma. Clin Cancer Res 2005, 11(22):8208-8212.

16. Pourgholami MH, Yan CZ, Lu Y, Wang L, Morris DL: Albendazole: a potent inhibitor of vascular endothelial growth factor and malignant ascites formation in OVCAR-3 tumor-bearing nude mice. Clin Cancer Res 2006, 12(6):1928-1935.

17. Dvorak HF, Brown LF, Detmar M, Dvorak AM: Vascular permeability factor/ vascular endothelial growth factor, microvascular hyperpermeability, and angiogenesis. Am J Pathol 1995, 146:1029-1039.

18. Paley PJ, Staskus KA, Gebhard K, Mohanraj D, Twiggs LB, Carson LF, Ramakrishnan S: Vascular endothelial growth factor expression in early stage ovarian carcinoma. Cancer 1997, 80(1):98-106.

19. Boocock CA, Charnock-Jones DS, Sharkey AM, McLaren J, Barker PJ, Wright KA, Twentyman PR, Smith SK: Expression of vascular endothelial growth factor and its receptors flt and KDR in ovarian carcinoma. J Natl Cancer Inst 1995, 87(7):506-516.

20. Schilder RJ, Pathak HB, Lokshin AE, Holloway RW, Alvarez RD, Aghajanian C, Min H, Devarajan K, Ross E, Drescher CW, Godwin AK: Phase II trial of single agent cetuximab in patients with persistent or recurrent epithelial ovarian or primary peritoneal carcinoma with the potential for dose escalation to rash. Gynecol Oncol 2009, 113:21-27.

21. Whitmore MM, DeVeer MJ, Edling A, Oates RK, Simons B, Lindner D, Williams BR: Synergistic activation of innate immunity by doublestranded RNA and CpG DNA promotes enhanced antitumor activity. Cancer Res 2004, 64:5850-5860.

22. Benard J, Da Silva J, De Blois MC, Boyer P, Duvillard P, Chiric E, Riou G: Characterization of a human ovarian adenocarcinoma line, IGROV1, in tissue culture and in nude mice. Cancer Res 1985, 45:4970-4979.

23. Correale P, Botta C, Cusi MG, Del Vecchio MT, De Santi MM, Gori SG, Bestoso E, Apollinari S, Mannucci S, Marra M, Abbruzzese A, Aquino A, Turriziani M, Bonmassar L, Caraglia M, Tagliaferri P: Cetuximab +/chemotherapy enhances dendritic cell-mediated phagocytosis of colon cancer cells and ignites a highly efficient colon cancer antigen-specific cytotoxic T-cell response in vitro. Int J Cancer 2012, 130(7):1577-1589.

24. Kobold S, Hegewisch-Becker S, Oechsle K, Jordan K, Bokemeyer C, Atanackovic D: Intraperitoneal VEGF inhibition using bevacizumab: a potential approach for the symptomatic treatment of malignant ascites? Oncologist 2009, 14(12):1242-1251.

25. Roda JM, Parihar R, Carson WE III: CpG-containing oligodeoxynucleotides act through TLR9 to enhance the NK cell cytokine response to antibodycoated tumor cells. J Immunol 2005, 175(3):1619-1627.

26. Moreno M, Mol BM, von Mensdorff-Pouilly S, Verheijen $\mathrm{RH}$, von Blomberg BM, Van Den Eertwegh AJ, Scheper RJ, Bontkes HJ: Toll-like receptor agonists and invariant natural killer T-cells enhance antibody-dependent cell-mediated cytotoxicity (ADCC). Cancer Lett 2008, 272(1):70-76.

27. Friedberg JW, Kelly JL, Neuberg D, Peterson DR, Kutok JL, Salloum R, Brenn T, Fisher DC, Ronan E, Dalton V, Rich L, Marquis D, Sims P, Rothberg PG, Liesveld J, Fisher Rl, Coffman R, Mosmann T, Freedman AS: Phase II study of a TLR-9 agonist (1018 ISS) with rituximab in patients with relapsed or refractory follicular lymphoma. Br J Haematol 2009, 146(3):282-291.

28. Lopez-Albaitero A, Lee SC, Morgan S, Grandis JR, Gooding WE, Ferrone S, Ferris RL: Role of polymorphic Fc gamma receptor IIla and EGFR expression level in cetuximab mediated, NK cell dependent in vitro cytotoxicity of head and neck squamous cell carcinoma cells. Cancer Immunol Immunother 2009, 58:1853-1864.

29. Kurai J, Chikumi H, Hashimoto K, Yamaguchi K, Yamasaki A, Sako T, Touge H, Makino H, Takata M, Miyata M, Nakamoto M, Burioka N, Shimizu E: Antibody-dependent cellular cytotoxicity mediated by cetuximab against lung cancer cell lines. Clin Cancer Res 2007, 13(5):1552-1561.
30. Okita R, Mougiakakos D, Ando T, Mao Y, Sarhan D, Wennerberg E, Seliger B, Lundqvist A, Mimura K, Kiessling R: HER2/HER3 signaling regulates NK cellmediated cytotoxicity via MHC class I chain-related molecule A and B expression in human breast cancer cell lines. J Immunol 2012, 188(5):2136-2145.

31. Mimura K, Kono K, Maruyama T, Watanabe M, Izawa S, Shiba S, Mizukami Y, Kawaguchi Y, Inoue M, Kono T, Choudhury A, Kiessling R, Fujii H: Lapatinib inhibits receptor phosphorylation and cell growth and enhances antibody-dependent cellular cytotoxicity of EGFR- and HER2overexpressing esophageal cancer cell lines. Int J Cancer 2011, 129(10):2408-2416.

32. Kim H, Kim SH, Kim MJ, Kim SJ, Park SJ, Chung JS, Bae JH, Kang CD: EGFR inhibitors enhanced the susceptibility to NK cell-mediated lysis of lung cancer cells. J Immunother 2011, 34(4):372-381.

33. Ahsan A, Hiniker SM, Ramanand SG, Nyati S, Hegde A, Helman A, Menawat R, Bhojani MS, Lawrence TS, Nyati MK: Role of epidermal growth factor receptor degradation in cisplatin-induced cytotoxicity in head and neck cancer. Cancer Res 2010, 70(7):2862-2869.

34. Sano D, Matsumoto F, Valdecanas DR, Zhao M, Molkentine DP, Takahashi Y, Hanna EY, Papadimitrakopoulou V, Heymach J, Milas L, Myers JN: Vandetanib restores head and neck squamous cell carcinoma cells' sensitivity to cisplatin and radiation in vivo and in vitro. Clin Cancer Res 2011, 17(7):1815-1827.

35. Zhang Y, Xing X, Zhan H, Li Q, Fan Y, Zhan L, Yu Q, Chen J: EGFR inhibitor enhances cisplatin sensitivity of human glioma cells. J Huazhong Univ Sci Technolog Med Sci 2011, 31(6):773-778.

36. Weng $Y$, Wang $Y$, Shi $Y$, Zhou W, Wang H, Wang C: TLR9 expression and its role in chemosensitivity to DDP in human cervical cancer cells in vitro. J Huazhong Univ Sci Technolog Med Sci 2011, 31(4):550-554.

doi:10.1186/1479-5876-11-25

Cite this article as: Sommariva et al:: High efficacy of CpG-ODN Cetuximab and Cisplatin combination for very advanced ovarian xenograft tumors. Journal of Translational Medicine 2013 11:25.

\section{Submit your next manuscript to BioMed Central and take full advantage of:}

- Convenient online submission

- Thorough peer review

- No space constraints or color figure charges

- Immediate publication on acceptance

- Inclusion in PubMed, CAS, Scopus and Google Scholar

- Research which is freely available for redistribution

Submit your manuscript at www.biomedcentral.com/submit
C) Biomed Central 